\title{
Institution of Electrical Engineers' Library of Sound Films
}

$\mathrm{T}^{\mathrm{H}}$ $\mathrm{HE}$ Institution of Electrical Engineers is collecting a library of sound films made by eminent electricians and electrical engineers. It is hoped that they will be of interest not only to subsequent generations but also to many local centres of the Institution overseas. Sound films have already been taken of Sir J. J. Thomson, Sir Ambrose Fleming, Mr. W. M. Mordey and others. After being introduced by the president of the Institution, the speaker makes a short address giving a review of the progress made in electrical science or engineering from his earliest days and sometimes trying to foretell the trend of development in the future. We have pleasure in printing below the address given by Sir Oliver Lodge for this library.

I have lived from the very beginning of the electrical age that is now upon us. When I was young there was no such thing as a dynamo. If we wanted a current of any magnitude, say for instance to supply an electric arc, we had in those days to mess about with a Grove's battery, consisting of zine, platinum and acids, and it was a troublesome business. I remember that the name 'dynamo' was invented by Lord Kelvin in a paper before Section A of the British Association, when I was a secretary to that body.

I remember seeing the original Paccinotti machine, which soon developed into the Gramme armature; and then ingeniously the Siemens firm introduced a double-winding and made the modern Siemens armature; there had been an old Siemens armature, with an iron rail wound longitudinally, which was shown at the 1862 Exhibition producing strong currents, and exciting much interest. It was no easy matter to get a really strong current in those days: covered wire was almost a novelty, while to make connexion between different things there was no notion of plugging in two terminals; we had to screw up each wire with a binding screw ; a pair of binding screws were the only terminals.

I remember the first electric lamp shown to the Telegraph Engineers by Mr. (later Sir Joseph) Swann, which he said would serve well for a reading-lamp, and not require any matches for its lighting up. And a little later I remember Colonel Crompton coming for one of the conversaziones at University College, London, and bringing a number of such lamps, which he arranged in the entrance hall, festooning them as an exhibition. He came himself and superintended the erection with extraordinary energy, taking possession of Carey Foster's laboratory, and having it all rigged up in time.

I remember too the first visit of Graham Bell and his demonstration of the telephone at South Kensington, when he lectured to the Physical Society in a most beautifully articulate manner, pronouncing everything completely and accurately. He was just the right type of man to make a metal disc speak.

Then Hertz made a great advance; he discovered how to produce and detect waves in space ; thus bringing the ether into practical use, harnessing it for the transmission of intelligence, in a way which has subsequently been elaborated by a number of people.

Now, this present century, which has made many undoubted discoveries in physics, seeks to discredit and deny the ether of space; and I want to conclude this talk by a few words upholding its reality. It is the ether which conveys waves in the fraction of a second to the antipodes, it is that which brings us information from the stars and the most distant nebulæ, which otherwise we should be without. The ether is the seat of all radiation energy, and indeed of all other energy, whether it be in the form of light or other waves. I remember when the nature of light was not known. Clerk Maxwell's great paper dated from the year 1864 or maybe ' 65 , when I was just leaving school and was not awake to its magnificence. I did not know of it till the 'seventies ; but in 1873 his great book on electricity appeared, and that year I attended my first meeting of the British Association, at Bradford, and heard it spoken of. This was a book worthy to be mentioned in the same breath as the "Principia".

Newton and Maxwell are among the glories of the human race; and they did for the ether something magnificent which has not been surpassed by any work of man. The ether is the vehicle of gravitation and of light. Its theory is not complete even yet. We are still groping after their great and unfinished discoveries. Einstein has shown us something more about gravitation, and has done away with action at a distance; and Planck has discovered the law regulating the interaction of ether and matter, so that radiation is only produced and destroyed in discontinuous quanta. But interference shows that radiation and the ether are continuous in free space, and that quanta only make themselves evident at the beginning and end of radiation-at the generation and absorption of light-when the ether is associated with the discontinuous thing that we call matter. 
I have here indicated what will be the work of the twentieth century; to complete the theory of the ether and to show how all things lead to an intelligible and concrete reality, very different from the abstractions and confusions under which we now, for the time, labour. Yet the present is a phase through which we had to go: it is an intermediate era in physics, through which we are guided by great men, Eddington and Jeans and Dirac, men who are contributing a great deal to physics and astronomy, work which we could not do without, and which forms a necessary avenue to the clear open space beyond.
Before the end of the twentieth century, as I think, or at any rate in the twenty-first, the ether will be recognised as the one means of communication between the atoms, and the whole of physics will become once more luminous and clear, constituting a glorious epoch for our descendants. The ether will come into its own again, not only for practical purposes as the seat of all potential energy, but with a clear understanding of it as the one substance that holds the universe together, in which all matter is embedded, without which even locomotion cannot be properly understood, and which constitutes the physical vehicle for life and mind.

OLIVER LODGE.

\section{Scientific Centenaries in 1935 \\ By Eng. Capt. Edgar C. Smith, o.B.e., R.N.}

GLANCING back once again over the history of science during the last few centuries with the object of recalling those men of science whose centenaries occur during the coming year, it is but natural to turn to the early records of the Royal Society.

In these, over and over again, is found the name of Robert Hooke, who was born on July 18, 1635, three hundred years ago. A scholar of Westminster School and a graduate of Christ Church, Oxford, he became the friend of Willis, Boyle, Wilkins, Seth Ward and others. On November 12, 1662, he was appointed curator of experiments to the Royal Society and on June 3, 1663, was elected a fellow of the Society. Two years later he was made professor of geometry in Gresham College, and it was in his apartments in Gresham's old mansion in the City of London that he passed the greater part of his life. A long list of papers and experiments testify to his ingenuity and versatility, and no doubt in due course tribute will be paid to his memory. "As to his Person," said Benjamin Martin in his "Biographia Philosophica", "he made but a mean Appearance, being very small and somewhat crooked; but he had an active, penetrating, indefatigable Genius, sparing no Pains in Quest of the Truth in Relation to whatever came under his Consideration. ...." Hooke died on March 3, 1703 and was buried in St. Helen's Church, Bishopgate ; a church which probably has more associations with the Royal Society than any other.

Two contemporaries of Hooke's abroad were Johann Becher (1635-1682) and Christoph Sturm (1635-1703). Becher was one of the first chemists to cast off the mystical language of the alchemists, and in his writings can be found the germ of the phlogiston theory. $\mathrm{He}$ wrote much, travelled widely, and only a short time before his death came to England to visit the Cornish mines. Sturm, who was also a German, was professor of physical science in the University of Altdorf, and is remembered as an advocate of the teaching of science in schools. In their day, Germany was slowly recovering from the inconceivable miseries of the Thirty Years War, during which, it is said, the population fell from $20,000,000$ to $4,000,000$.

It was in 1635 in the midst of that war that Wilhelm Sohickard (1592-1635) and Johann Faulhaber (1580-1635) died. The latter was an able mathematician who was acquainted with Descartes, while the former was known to Kepler and to Gassendi. It was to Gassendi that Schickard sent his observations of the transit of Mercury of 1633.

The work of these scientific worthies belongs almost entirely to the seventeenth century, a period during which, says Cajori, the progress of physics was truly extraordinary. During the eighteenth century, he says, physics proper was cultivated by men of more limited powers than those of Galileo, Huygens and Newton. For all that, however, there was great activity in various branches of science, especially in mathematics and astronomy, and in England practical astronomy made wonderful advances.

To these advances a succession of clever mechanicians contributed, and of all the British men of science born two hundred years ago none has a more interesting record than Jesse Ramsden (1735-1800), who from a clothworkers' apprentice at Halifax rose to be the leading instrument maker in London. "Esteemed by the great, cherished by his friends and loved by his servants and workmen", Ramsden was called by Delambre "le plus grand de tous les artistes". From Ramsden's shop in Piccadilly came some of the finest telescopes and theodolites. $\mathrm{He}$ was elected a fellow of the Royal Society in 1786 and nine years 